\title{
Business Strategy of Top Indian Company: L\&T InfoTech
}

\author{
Revathi R. ${ }^{1}$, Madhushree ${ }^{2}$, \& P. S. Aithal ${ }^{3}$ \\ ${ }^{1,2}$ Research Scholar, Srinivas Institute of Management Studies, Srinivas University, \\ Mangalore - India \\ ${ }^{3}$ Srinivas Institute of Management Studies, Srinivas University, Mangalore - India \\ E-mail: revathiradhakrishnan93@gmail.com
}

Type of the Paper: Research Case Study.

Type of Review: Peer Reviewed.

Indexed In: OpenAIRE.

DOI: http://dx.doi.org/10.5281/zenodo.1302770.

Google Scholar Citation: $\underline{\text { IJCSBE}}$

How to Cite this Paper:

Revathi, R., Madhushree, \& Aithal, P. S. (2018). Business Strategy of Top Indian Company: L\&T InfoTech. International Journal of Case Studies in Business, IT and Education (IJCSBE), 2(1), 64-89. DOI: http://dx.doi.org/10.5281/zenodo.1302770.

International Journal of Case Studies in Business, IT and Education (IJCSBE)

A Refereed International Journal of Srinivas University, India.

(C) With Authors.

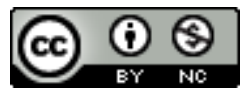

This work is licensed under a Creative Commons Attribution-Non Commercial 4.0 International License subject to proper citation to the publication source of the work.

Disclaimer: The scholarly papers as reviewed and published by the Srinivas Publications (S.P.), India are the views and opinions of their respective authors and are not the views or opinions of the S.P. The S.P. disclaims of any harm or loss caused due to the published content to any party. 


\title{
Business Strategy of Top Indian Company: L\&T InfoTech
}

\author{
Revathi R. ${ }^{1}$, Madhushree ${ }^{2}$, \& P. S. Aithal ${ }^{3}$ \\ ${ }^{1,2}$ Research Scholar, Srinivas Institute of Management Studies, Srinivas University, \\ Mangalore - India \\ ${ }^{3}$ Srinivas Institute of Management Studies, Srinivas University, Mangalore - India \\ E-mail: revathiradhakrishnan93@gmail.com
}

\begin{abstract}
L\&T InfoTech is one of the fastest growing Information Technology companies in India. Founded in 1997, as an Indian IT company, L\&T InfoTech has it's headquarters at Mumbai, Maharashtra and is owned by Larsen \& Toubro. L\&T InfoTech offers its services to various industries like Banking and financial services, Communication and media technology, Insurance, Manufacturing, Retail, Hi-tech, Consumer Goods \& Distribution, Energy Resources \& Utilities, Life Science \& Health Care, Public Services, Travel, Transportation, and Hospitality. L\&T InfoTech is an Information Technology service provider offering business solutions with latest innovative ideas and technology to needy customers around the world. L\&T is one of the top 10 listed companies in India. This paper throws light on various aspects which made L\&T InfoTech a unique company with its innovative service offers through its slogan 'Welcome to Possible' to various industries and industry sectors. This case study paper also discusses the strategy of L\&T InfoTech while providing services for different sectors like Banking, Insurance, Energy and Utilities, CPG \& Retail, Hi-tech, Life Science and Healthcare, Media and Entertainment, and Manufacturing. In this case study, we have analysed the operational strategy, business strategy, financial stability, marketing mix, competitors, training, and recruitment strategy of the company briefly using Theory A. We have also studied the CSR procedure of the company and analyzed its strategies using SWOT framework as research case study.
\end{abstract}

Keywords: L\&T InfoTech, Case study, Welcome to possible, Business strategy of IT Company.

\section{INTRODUCTION :}

Larsen \& Toubro, commonly known as L\&T, is an Indian multi-national company headquartered in Mumbai, Maharashtra, India. L\&T InfoTech Limited is a well known Information Technology services provider and solutions provider around the world. L\&T InfoTech has a global existence which includes 10 software development centers in India at 7 locations and 15 intercontinental offices. L\&T has a strong clients base which includes industry leaders like Chevron Free scale, Hitachi, Sanyo, and Lafarge. Larsen \& Toubro InfoTech i.e., L\&T InfoTech incorporated in the year 1997 as a fully owned subsidiary of the 3.3 billion Euro technology-driven construction and engineering major Larsen \& Toubro Limited. They provide service to different sectors like Banking, Insurance, Energy and Utilities, CPG \& Retail, Hi-tech, Life Science and Healthcare, Media and Entertainment, and Manufacturing. They are one of the major information technology service provider and also solution provider to a large number of the client all over the globe [1], [2], [3]. L\&T is helping organization across Europe, North America, and India and it provides various services all over the world which are as follows:

(1) Automated identification and customs classification of private data in the distributed system, leading to time and cost saving of more than $50 \%$ for a global oil and gas major.

(2) Hybrid assessment of 51 SAP, Oracle and sales force applications, covering 39 business processes, leading $80 \%$ effort reduction in data mapping for a US-based manufacturer. 
(3) Scanned 15 TB data across 800 end-point devices and serves in four weeks, to start a smooth implementation phase, leading to $75 \%$ in cost saving for a Danish retailer.

(4) Automated data subject rights management, data obfuscation in a core and semantic layers, and pseudonymization of sensitive data leading to cost savings of $75 \%$ for a US-based multinational technology company [1].

Larsen \& Toubro was originated from a company founded in 1938 by two Danish engineers named Henning Holck-Larsen and Soren Kristian Toubro in Mumbai. The company was formed as a representative for Danish dairy equipment manufacturer. In 1939 when the second world war started, Henning Holck-Larsen and Soren Kristian Toubro started small workshop to take care of jobs and provide services as the import was restricted due to war. The supply of Danish product was stopped due to the invasion of Germany in Denmark. During the war time, repairs and refit of the ships were required and it opened the opportunity for the L\&T. They provide repairs and refit for ships during the war and thus formed a new company called Hilda Ltd to take care of all the repairs and refit operations. It also started repairing fabricated ships after the formation of Hilda Ltd which became or held a stepping stone for the expansion of the company [3], [4].

Larsen \& Toubro InfoTech technology consulting and digital solutions company helped more than 250 clients around the world. They operate in 27 countries as a part of their expansion. L\&T hasten their digital transformation with LTI's Mosaic platform, which enables their mobile, social, analytics, and cloud journeys very easy and digitally. Larsen \& Toubro Limited's information and technology division was found 20 years ago, their unique legacy gives us supreme real-world expertise and proficiency to solve the most complex and compound challenges of organizations across every industry. Every day, more than 20,000 LTItes helps their clients to advance the effectiveness and value of their business and technology operations, and they deliver value to their customers, employees as well as the shareholders. L\&T has been a pioneer in contribution 'concept-to commissioning' engineering solutions across various verticals. The key competitive advantages across businesses include committed engineering design centers, competency cells, advanced formwork systems, project implementation capability, digitized project control and a pool of brilliant workforce. These have enabled the company to establish itself as one of the leading EPC solutions providers, in India and in targeted markets overseas. The company is characterized by professionalism, high standards of corporate governance and sustainability [1], [2], [3].

In the year 2001, the company name was changed from L\&T Information Technology Limited and renamed as Larsen \& Toubro InfoTech Limited. In the same year, L\&T InfoTech achieved the target to get in the assessed level of the SEI Level 5 which means that the company has a focus on continuous process improvement and technology which can be predicted and effectively implemented whenever it is required. A wholly functional, efficient, and broad Network Operations Centre (NOC) using CA Unicenter platform introduced at six locations around the globe by the company which is being used by 2000 workstations. The company developed capabilities in ample billing solutions for Telco which includes services like subscribers hierarchy management tariff and billing engine debt escalation engine etc. They also developed capabilities in order to setup Fraud Management Control Centres (FMCC). At the same year, the company provided an extensive series of both discrete and process manufacturing companies. It acquired significant depth in EProcurement \& Internet-based E-marketplaces and integration of the same with backend Enterprise Solutions like the SAP. In the year 2002 the company achieved the SEI CMM Level 5 for all development and verticals centers and in the same year the company has been flourishing in positioning itself for certain bulky outsourcing deals despite the volume handicap mainly by leveraging its ancestry of the L\&T Group. During the year 2004 the company acquired some key clients in ERP practices; financial services further consolidated its presence in the Manufacturing Communications and Embedded Systems space. In the same year, the company registered a significant growth in Exports Revenue (61\%) and the USA continues to be the leading destination contributing 63\% to the total software exports. During the year 2005 the company launched CMMi idea while continuing select programmes of six-sigma implementation. The launch and Certification of PCMM 5 enable the company in vastly enhancing the capability to deal optimally with the human resources which constitute practically the entire value-adding constituency in this industry. During the year 2006, the company acquired 'GDA Technologies Inc.' USA (GDA) for USD 27 million and 
in the same year the company continued to focus on the chosen verticals; Banking Financial Services and Insurance Energy and Petrochemicals Product Engineering services (comprising of Communications and Embedded Software) and Manufacturing. During the year 2007, the company did considerable hard work on 'Campus Branding' in order to catch the attention of talented people from the campuses around the globe. L\&T also launched a new website for them and many other marketing strategies and collaterals which are in line with its brand memo of 'Business-toInformation Technology Connect'. In the same year, the company extended and developed its infrastructure with the addition of two new development centers one in Navi Mumbai and the other in Bangalore. In the year 2008 L\&T launched two new series lines- consulting service line and testing service line in order to convert the company into a full-service Information Technology provider [1], [4].

\section{OBJECTIVE :}

- To know the growth saga of a successful IT company in India.

- To study the Business strategy and, Operational strategy of the company.

- To know the competitors and the products and services offered by them as compared to L\&T.

- To know the financial status of the company from the past 5 years.

- To know the recruitment and training strategy of L\&T InfoTech.

- To study the Marketing strategy and mix of the company.

- To know various solutions provided by L\&T.

- To look into the Corporate social responsibility model of the company and its effort on Environmental sustainability.

\section{METHODOLOGY :}

The data is collected through secondary sources such as journals, published papers, and company websites.

\section{COMPETITORS OF L\&T INFOTECH :}

L\&T is a multinational company with a large number of product and services. There are large numbers of competitors for L\&T InfoTech doing the same business in the same sector and competing among each other to increase their profitability. Table 1 lists the competitors of L\&T InfoTech on the basis of its market capital, sales, net profit, and net assets [5].

Table 1 : List of competitors of L\&T InfoTech on the basis of its market capital, sales, net profit and net assets [5].

\begin{tabular}{|c|c|c|c|c|c|}
\hline Sl.No. & $\begin{array}{c}\text { Name of the } \\
\text { Company }\end{array}$ & $\begin{array}{c}\text { Market } \\
\text { Capital }\end{array}$ & Sales & Net Profit & Total Assets \\
\hline 1 & TCS & $6,67,205.80$ & $97,356.00$ & $25,241.00$ & $78,266.00$ \\
\hline 2 & Infosys & $2,61,647.50$ & $61,941.00$ & $16,155.00$ & $68,017.00$ \\
\hline 3 & Wipro & $1,32,083.39$ & $44,710.00$ & $7,722.80$ & $52,176.40$ \\
\hline 4 & HCL Tech & $1,28,810.04$ & $22,073.00$ & $7,362.00$ & $26,004.53$ \\
\hline 5 & Tech Mahindra & $66,077.93$ & $23,165.39$ & $3,047.33$ & $17,933.00$ \\
\hline & Oracle Financial & & & & \\
\hline 6 & Services & $34,393.90$ & $3,861.73$ & $1,005.99$ & $2,675.93$ \\
\hline 7 & L\&T InfoTech & $\mathbf{2 7 , 9 5 3 . 1 2}$ & $\mathbf{6 , 1 8 2 . 9 0}$ & $\mathbf{9 3 7 . 6}$ & $\mathbf{2 , 9 7 5 . 7 0}$ \\
\hline 8 & MphasiS & $20,196.31$ & $3,274.87$ & 739.89 & $4,695.33$ \\
\hline 9 & Mindtree & $16,553.28$ & $5,325.00$ & 624.9 & $2,853.30$ \\
\hline 10 & Hexaware Tech & $12,725.79$ & $1,524.11$ & 410.96 & $1,541.70$ \\
\hline 11 & Cyient & $9,361.87$ & $1,439.70$ & 401.8 & $1,865.90$ \\
\hline 12 & Tata Elxsi & $7,217.84$ & $1,386.30$ & 240.04 & 557.96 \\
\hline 13 & NIIT Tech & $6,662.22$ & $1,645.90$ & 226.2 & $1,349.20$ \\
\hline
\end{tabular}


International Journal of Case Studies in Business, IT and Education (IJCSBE), ISSN: 2581-6942, Vol. 2, No. 1, June 2018.

\begin{tabular}{|c|c|c|c|c|c|}
\hline 14 & Persistent & $6,291.60$ & $1,732.75$ & 342.12 & $1,813.70$ \\
\hline 15 & Zensar Tech & $5,410.51$ & $1,285.81$ & 192.58 & $1,140.39$ \\
\hline 16 & Polaris Consult & $4,845.30$ & $1,817.31$ & 180.82 & 759.9 \\
\hline 17 & Intellect Desig & $2,719.39$ & 671.48 & 32.85 & 681.33 \\
\hline 18 & Quick Heal Tech & $2,325.98$ & 316.22 & 78.88 & 665.46 \\
\hline 19 & 8K Miles Soft & $1,998.90$ & 37.46 & 2.26 & 109.51 \\
\hline 20 & Hinduja Global & $1,939.83$ & $1,597.54$ & 101.53 & $1,134.31$ \\
\hline 21 & Geometric & $1,754.05$ & 423.12 & 97.68 & 487.1 \\
\hline 22 & Newgen Software & $1,753.39$ & - & - & - \\
\hline 23 & Sasken Tech & $1,745.23$ & 421.4 & 83 & 541.68 \\
\hline 24 & Hinduja Venture & $1,665.51$ & 242.58 & 125.65 & $1,290.19$ \\
\hline 25 & Infinite Comp & $1,657.53$ & 383.31 & 91.8 & 553.16 \\
\hline 26 & Ramco System & $1,347.19$ & 277.94 & 50.68 & 690.14 \\
\hline 27 & Mastek & $1,340.11$ & 162.32 & 15.74 & 232.03 \\
\hline 28 & Rolta & 883.46 & $1,454.91$ & 105.49 & $5,022.80$ \\
\hline 29 & 3i Infotech & 678.52 & 237.51 & -86.71 & $1,261.23$ \\
\hline 30 & SQS India BFSI & 609.31 & 276.44 & 28.01 & 103.93 \\
\hline 31 & 63 Moons Tech & 384.76 & 150.06 & 49.08 & $3,342.54$ \\
\hline 32 & AGC Networks & 320.39 & 245.96 & -14.52 & 192.95 \\
\hline 33 & Blue Star Info & 313.15 & 138.21 & 11.69 & 106.06 \\
\hline 34 & Fourth Dimensio & 297.35 & $1,490.85$ & 21.96 & 73.11 \\
\hline 35 & Saksoft & 260.28 & 50.68 & 6.88 & 106.15 \\
\hline 36 & Ducon Infratech & 243.11 & 40.82 & 0.69 & 33.74 \\
\hline 37 & Innovana & 182.45 & - & - & - \\
\hline 38 & Mindteck & 146.06 & 83.64 & 5.43 & 179.99 \\
\hline 39 & Softtech Engine & 75.38 & - & - & - \\
\hline 40 & Sphere Global & 55.72 & 4.21 & 1.35 & 22.81 \\
\hline 41 & Dev Information & 46.37 & 56.52 & 2.9 & 23.01 \\
\hline 42 & Bodhtree Cons & 27.54 & 78.76 & 2.67 & 39.73 \\
\hline 43 & Keerti Knowledg & 18.91 & 1.23 & 0.2 & 2.19 \\
\hline 44 & ICSA & 11.31 & 2.76 & -8.76 & -440.78 \\
\hline 45 & Bharatiya Glob & 7.68 & 40.21 & 0.88 & 95.32 \\
\hline 46 & Acropetal Tech & 6.61 & - & -2.09 & 131.51 \\
\hline
\end{tabular}

There are 46 companies which are list in the exchange market as the competitors of the L\&T InfoTech. The major competitors of the L\&T InfoTech are TCS, Infosys, Wipro, HCL Tech, Tech Mahindra, Oracle Financial Services which have net profit and sales more than L \& T InfoTech in the IT Sector. They provide the same product and services provided by L\&T InfoTech and listed as the major competitors in the services they serve.

\section{MAJOR PRODUCT AND SERVICES OF L\&T \& ITS COMPETITORS :}

Among the 46 companies in the same field 10 companies are considered to the major competitors who provide similar products and services to their client. These 10 companies are listed as the top 10 IT companies during 2017. The major products and services provided by L\&T InfoTech and its competitors in same industry is depicted in Table 2.

Table 2 : The table shows the product and services provided by L\&T InfoTech and its competitors in same industry.

\begin{tabular}{|l|l|l|lr|}
\hline $\begin{array}{c}\text { S.N } \\
\mathbf{0}\end{array}$ & $\begin{array}{c}\text { Compan } \\
\mathbf{y}\end{array}$ & \multicolumn{2}{|c|}{ Industry } & \multicolumn{2}{|c|}{ Product and services } \\
\hline 1 & TCS & $\begin{array}{l}\text { Banking and financial services, } \\
\text { Communication }\end{array}$ & $\begin{array}{l}\text { Application and } \\
\text { maintenance, Asset leverage solution, }\end{array}$ \\
\hline
\end{tabular}




\begin{tabular}{|c|c|c|c|}
\hline & & $\begin{array}{l}\text { technology, } \\
\text { Manufacturing, Retail, Hi-tech, } \\
\text { Consumer Goods \& Distribution, } \\
\text { Energy resources \& Utilities, Life } \\
\text { Science \& Health Care, Public } \\
\text { Services, Travel, Transportation \& } \\
\text { Hospitality [6]. }\end{array}$ & $\begin{array}{l}\text { Assurance services, Business process } \\
\text { outsourcing, Consulting, Engineering } \\
\text { and Industries services, Enterprises } \\
\text { solutions, IT infrastructure services [6]. }\end{array}$ \\
\hline 2 & Infosys & $\begin{array}{l}\text { Aerospace and Defence, Agriculture, } \\
\text { Airlines, Automotive, Cards and } \\
\text { Payments, Communication services, } \\
\text { Consumer packed goods, Education, } \\
\text { Financial Services, Healthcare, } \\
\text { High-tech, Hospitality and Leisure, } \\
\text { Industrial manufacturing, } \\
\text { Information services and publishing, } \\
\text { Insurance, Life science, Logistics } \\
\text { and distribution, Media and } \\
\text { entertainment, Oil and gas, Public } \\
\text { sector, Resource industries, Retail, } \\
\text { Utilities [7]. }\end{array}$ & $\begin{array}{l}\text { Banking suite, distributive trade, Big } \\
\text { data, Micro-Commerce, Cloud, Sourcing } \\
\text { and Procurement, Customer Services, } \\
\text { Consulting, Strategy and Architect, } \\
\text { Business Transformation, Enterprise } \\
\text { Processes, Enterprises Applications, } \\
\text { Technology Services, Outsourcing } \\
\text { services [7]. }\end{array}$ \\
\hline 3 & Wipro & 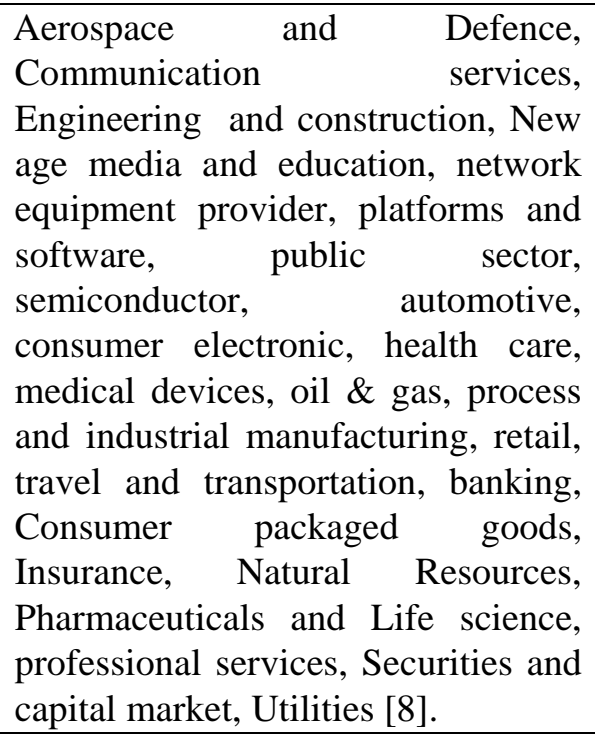 & $\begin{array}{l}\text { Analytical, applications, Business } \\
\text { process, Consulting, Infrastructure, } \\
\text { Product Engineering, Big data, Cyber } \\
\text { security and enterprise risk, Enterprise } \\
\text { ops transformation, Mobility, Block } \\
\text { chain, DevOps, Industry 4.0, Open } \\
\text { source, Cloud, Enterprise Architecture, } \\
\text { Product lifecycle management [8]. }\end{array}$ \\
\hline 4 & $\begin{array}{l}\text { HCL } \\
\text { Tech }\end{array}$ & $\begin{array}{l}\text { Aerospace and } \\
\text { Automotive, Befence, } \\
\text { Markets, Chemical and Process } \\
\text { Industries, Consumer goods, Energy } \\
\text { and Utilities, Health care, Hi-Tech, } \\
\text { Industrial Manufacturing, Insurance, } \\
\text { Life Science, Manufacturing } \\
\text { Industries, Media and } \\
\text { Entertainment, Mining and Natural } \\
\text { Resources, Oil and Gas, Retail, } \\
\text { Telecom, Travel, Transport logistics } \\
\text { and Hospitality [9]. }\end{array}$ & $\begin{array}{l}\text { Application development, application } \\
\text { maintenance, SAP, Microsoft, Oracle, } \\
\text { Business Assurance and Testing, } \\
\text { DRYiCE Autonomics and } \\
\text { Orchestration, SIAM for Application, } \\
\text { Data Center Service, Workplace service, } \\
\text { Network Services \& UCC, Application } \\
\text { Operations, Mainframe and AS400, } \\
\text { embedded, software, mechanical and } \\
\text { digital Engineering, Product Testing, } \\
\text { PLM, system Engineering, Hardware } \\
\text { Engineering, Supply chain Management, } \\
\text { Finance and Accounting services, } \\
\text { Digital and Content Service, Cognitive } \\
\text { Automation, Digital and Analytics, } \\
\text { Cloud native service, Cyber security and }\end{array}$ \\
\hline
\end{tabular}




\begin{tabular}{|c|c|c|c|}
\hline & & & GRC, IoT WoRKS [9]. \\
\hline 5 & $\begin{array}{l}\text { Tech } \\
\text { Mahindr } \\
\text { a }\end{array}$ & $\begin{array}{l}\text { Banking, financial services \& } \\
\text { Insurances, Communication, Media } \\
\text { \& Communication, Energy \& } \\
\text { Utilities, Health Care \& Life } \\
\text { science, Hi-Tech, Manufacturing, } \\
\text { Public sector \& Government, Retail } \\
\text { \& Consumer Goods, Travel } \\
\text { Transportation \& Logistics [10]. }\end{array}$ & 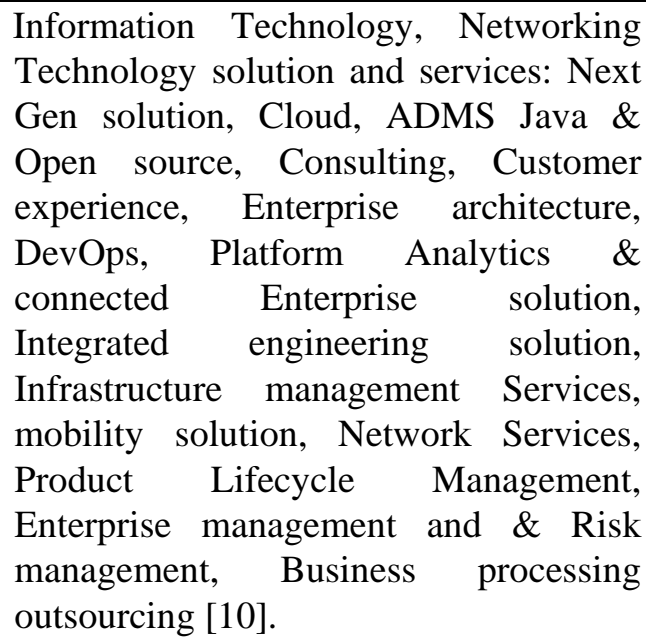 \\
\hline 6 & $\begin{array}{l}\text { Oracle } \\
\text { Financial } \\
\text { Services }\end{array}$ & $\begin{array}{l}\text { Aerospace and Defence, Chemicals, } \\
\text { Communications, Higher education, } \\
\text { Financial Services, Health Science, } \\
\text { Health care, High Technology, } \\
\text { Industrial Manufacturing, Life } \\
\text { Sciences, Construction and } \\
\text { Engineering, Hospitality, Retail, } \\
\text { Utilities, Media and entertainment, } \\
\text { Natural Resources, Oil and Gas, } \\
\text { Public Sector, Travel and } \\
\text { Transportation [11]. }\end{array}$ & $\begin{array}{l}\text { Cloud solutions, Cloud Application } \\
\text { (SaaS), Cloud Platform (PaaS), Cloud } \\
\text { Infrastructure (IaaS), Cloud Data, Cloud } \\
\text { marketplace, Applications, Database and } \\
\text { technologies, IT infrastructure, Industry } \\
\text { solution, Java, Small and Midsize } \\
\text { Business, Support and service, Training, } \\
\text { Partners, Developers, OTN, Downloads } \\
\text { and Trials [11]. }\end{array}$ \\
\hline 7 & $\begin{array}{l}\text { L\&T } \\
\text { InfoTech }\end{array}$ & $\begin{array}{l}\text { Banking, Insurance, Energy and } \\
\text { Utilities, CPG \& Retail, Hi-tech, } \\
\text { Life Science and Healthcare, Media } \\
\text { and Entertainment, and } \\
\text { Manufacturing [1]. }\end{array}$ & $\begin{array}{l}\text { Services: Cloud, Consulting, Cloud } \\
\text { Infrastructure and Security, Assurance } \\
\text { service, Cyber security, Applications } \\
\text { Management, Enterprise Solutions: } \\
\text { Oracle, SAP, Microsoft Dynamics, } \\
\text { Cloud apps, Maximo, Sales force, } \\
\text { Digital Transformation: Data \& } \\
\text { Analytics, Internet of things, Mobility, } \\
\text { Digital Integration, Artificial } \\
\text { Intelligence and cognitive, Platforms: } \\
\text { Mosaic, Industry Platform (Unirax, } \\
\text { REDaxis, iCEOn), Technology } \\
\text { Platform(Rapid Adopt) [1]. }\end{array}$ \\
\hline 8 & MphasiS & $\begin{array}{l}\text { Banking and Capital markets :Retail } \\
\text { banking, Credit cards and payments, } \\
\text { Wealth Management, Corporate } \\
\text { banking, Investment Banking, Asset } \\
\text { management, Insurance: Property \& } \\
\text { causality, Life and Retirement, } \\
\text { health, Communication, Energy \& } \\
\text { Utilities, Healthcare, Life Science, } \\
\text { logistics, Manufacturing, Travel and } \\
\text { Transportation [12]. }\end{array}$ & 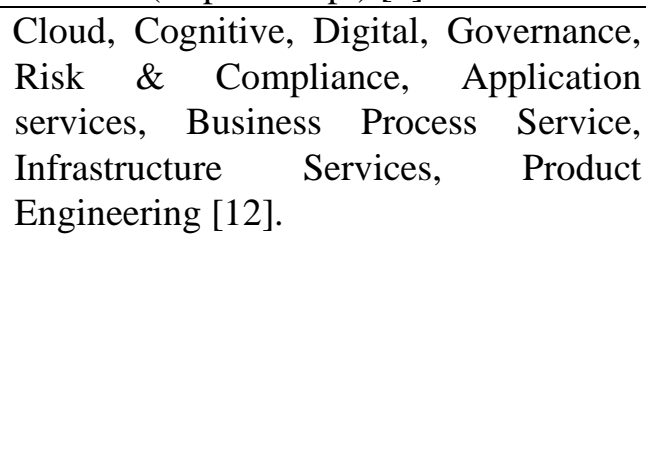 \\
\hline 9 & Mindtree & $\begin{array}{l}\text { Banking, Capital Market, Consumer } \\
\text { Electronics, Consumer } \quad \text { Packed }\end{array}$ & $\begin{array}{l}\text { Digital: Cloud, Data Analytics, Digital } \\
\text { Commerce, Digital Marketing, Mobility, }\end{array}$ \\
\hline
\end{tabular}




\begin{tabular}{|c|c|c|c|}
\hline & & 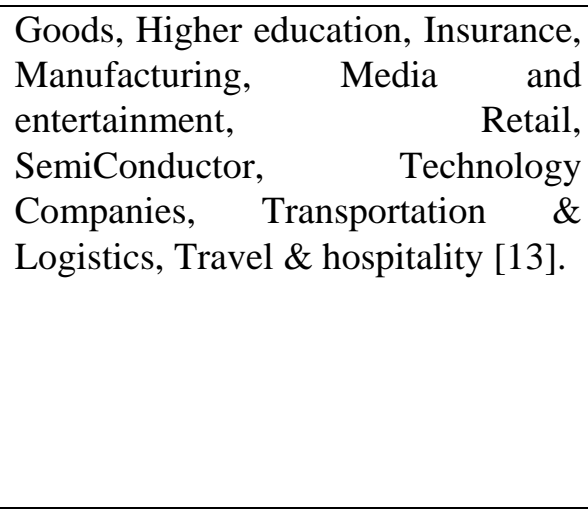 & $\begin{array}{l}\text { User Experience design, Portal } \\
\text { \&Collaboration, The digital pumpkin, } \\
\text { Operations: Agile, Application } \\
\text { development and Support, Automation, } \\
\text { Business Process management, } \\
\text { Infrastructure Management, Testing } \\
\text { Engineering, Integrated Services, IT } \\
\text { consulting : Application \& Infrastructure } \\
\text { Optimization, DevOps, Information } \\
\text { Strategy \& Governance, Quality } \\
\text { Assurance Strategy \& Process [13]. }\end{array}$ \\
\hline 10 & $\begin{array}{l}\text { Hexawar } \\
\text { e Tech }\end{array}$ & $\begin{array}{l}\text { Banking and Financial Services, } \\
\text { health care and Insurance, travel and } \\
\text { transportation, manufacturing and } \\
\text { Consumer, Professional Services } \\
\text { [14]. }\end{array}$ & $\begin{array}{l}\text { Application } \\
\text { Transformation } \\
\text { management, Application Management } \\
\text { Service, Business intelligence and } \\
\text { analytics, Business Process services, } \\
\text { Digital Assurance, Digital Customer, } \\
\text { Enterprise Solution, Infrastructure } \\
\text { management Services, Customer } \\
\text { Experience transformation [14]. }\end{array}$ \\
\hline
\end{tabular}

L\&T InfoTech provide services to Industries like Banking, Insurance, Energy and Utilities, CPG \& Retail, Hi-tech, Life Science and Healthcare, Media and Entertainment, and Manufacturing. The above listed are the 10 major competitors and they do same and similar services like L\&T InfoTech. L\&T InfoTech provides services in the major areas like Cloud, Consulting, Cloud Infrastructure and Security, Assurance service, Cyber security, Applications Management, Enterprise Solutions: Oracle, SAP, Microsoft Dynamics, Cloud apps, Maximo, Sales force, Digital Transformation: Data \& Analytics, Internet of things, Mobility, Digital Integration, Artificial Intelligence and cognitive, Platforms: Mosaic, Industry Platform (Unirax, REDaxis, iCEOn), Technology Platform (Rapid Adopt) [5-13]. Table 3 provides the comparative information on the competitors who provide similar services to the customers.

Table 3: The table shows the competitors provide the same product and services as of $\mathrm{L} \& \mathrm{~T}$ InfoTech [5-14].

\begin{tabular}{|c|c|c|c|c|c|c|c|c|c|}
\hline SERVICES & $\begin{array}{l}\text { Banki } \\
\text { ng }\end{array}$ & $\begin{array}{l}\text { Energ } \\
\text { y \& } \\
\text { Utiliti } \\
\text { es }\end{array}$ & $\begin{array}{l}\text { Retail } \\
\text { \& CPG }\end{array}$ & $\begin{array}{l}\text { Insuran } \\
\text { ce }\end{array}$ & $\begin{array}{l}\text { Hi- } \\
\text { Tech }\end{array}$ & $\begin{array}{l}\text { Life } \\
\text { Science }\end{array}$ & $\begin{array}{l}\text { Health } \\
\text { care }\end{array}$ & $\begin{array}{l}\text { Media } \\
\text { \& } \\
\text { Enterta } \\
\text { inment }\end{array}$ & $\begin{array}{l}\text { Manufac } \\
\text { turing }\end{array}$ \\
\hline \multirow{5}{*}{ COMPANY } & TCS & $\begin{array}{l}\text { Infosy } \\
\text { S }\end{array}$ & TCS & TCS & TCS & Infosys & Infosys & Infosys & TCS \\
\hline & Wipro & Wipro & Infosys & Infosys & $\begin{array}{l}\text { Infosy } \\
\text { s }\end{array}$ & $\begin{array}{l}\text { HCL } \\
\text { Tech }\end{array}$ & Wipro & $\begin{array}{l}\text { HCL } \\
\text { Tech }\end{array}$ & Infosys \\
\hline & $\begin{array}{l}\text { HCL } \\
\text { Tech }\end{array}$ & $\begin{array}{l}\text { HCL } \\
\text { Tech }\end{array}$ & Wipro & Wipro & Wipro & $\begin{array}{l}\text { Oracle } \\
\text { financia } \\
\text { l } \\
\text { services }\end{array}$ & $\begin{array}{l}\text { HCL } \\
\text { Tech }\end{array}$ & $\begin{array}{l}\text { Oracle } \\
\text { financia } \\
\text { l } \\
\text { services }\end{array}$ & Wipro \\
\hline & $\begin{array}{l}\text { Mphas } \\
\text { is }\end{array}$ & $\begin{array}{l}\text { Mphas } \\
\text { is }\end{array}$ & $\begin{array}{l}\text { Oracle } \\
\text { financia } \\
1 \\
\text { services }\end{array}$ & Mphasis & $\begin{array}{l}\text { Mphas } \\
\text { is }\end{array}$ & Mphasis & $\begin{array}{l}\text { Oracle } \\
\text { financia } \\
\text { l } \\
\text { services }\end{array}$ & $\begin{array}{l}\text { Mindtre } \\
\mathrm{e}\end{array}$ & $\begin{array}{l}\text { HCL } \\
\text { Tech }\end{array}$ \\
\hline & $\begin{array}{l}\text { Mindt } \\
\text { ree }\end{array}$ & $\begin{array}{l}\text { Oracle } \\
\text { financ } \\
\text { ial } \\
\text { servic }\end{array}$ & $\begin{array}{l}\text { Mindtre } \\
\text { e }\end{array}$ & $\begin{array}{l}\text { Mindtre } \\
\text { e }\end{array}$ & $\begin{array}{l}\text { Mindt } \\
\text { ree }\end{array}$ & $\begin{array}{l}\text { Tech } \\
\text { Mahind } \\
\text { ra }\end{array}$ & Mphasis & & $\begin{array}{l}\text { Oracle } \\
\text { financial } \\
\text { services }\end{array}$ \\
\hline
\end{tabular}


International Journal of Case Studies in Business, IT and Education (IJCSBE), ISSN: 2581-6942, Vol. 2, No. 1, June 2018.

\begin{tabular}{|l|l|l|l|l|l|l|l|l|l|}
\hline & & es & & & & & & & \\
\cline { 2 - 9 } & Tech \\
$\begin{array}{l}\text { Mahin } \\
\text { dra }\end{array}$ & $\begin{array}{l}\text { Tech } \\
\text { Mahin } \\
\text { dra }\end{array}$ & $\begin{array}{l}\text { Tech } \\
\text { Mahind } \\
\text { ra }\end{array}$ & $\begin{array}{l}\text { Tech } \\
\text { Mahind } \\
\text { ra }\end{array}$ & $\begin{array}{l}\text { Tech } \\
\text { Mahin } \\
\text { dra }\end{array}$ & & $\begin{array}{l}\text { Tech } \\
\text { Mahind } \\
\text { ra }\end{array}$ & & Mphasis \\
\cline { 2 - 9 } \\
Hexa & & & $\begin{array}{l}\text { Hexawa } \\
\text { re Tech } \\
\text { Tech }\end{array}$ & $\begin{array}{l}\text { Hexa } \\
\text { ware } \\
\text { Tech }\end{array}$ & & $\begin{array}{l}\text { Hexawa } \\
\text { re Tech }\end{array}$ & & Mindtree \\
& & & & & & & & & $\begin{array}{l}\text { Hexaware } \\
\text { Tech }\end{array}$ \\
\hline
\end{tabular}

\section{OPERATIONAL STRATEGY OF L\&T INFOTECH :}

L \& T Info tech is a company which operates in 8 sectors in different countries and has more than 250 clients all over the world. Operational strategy of L\&T InfoTech deals with the product design, location, Layout, process design, human resource and job design, inventory, reliability and maintenance, quality management, schedule and procurement [15][16]. L\&T Info tech is a company which operates in 8 sectors in different countries with more than 250 clients all over the world. Its helps their clients to digitalise the activities, provide cloud based solutions over traditional onpremises one which accelerates deployment, optimized costs and on-demand scalability associated with Cloud and Software-as-a-Service (SaaS) models. Analytical and information management strategy access to extraordinary volumes of data, originated from social media, transactional data and enterprise data sets as well as connected devices,. They completely provide an IT environment for the clients and they yield continuously and improve the operations. L\&T offers a perfect Transformation and operation support service which carry out the business operation smoothly and maintain the excellence of clients.

LTI has operations in 27 countries which offers Analytics \& Information Management, Applications Management, Cloud Computing, Enterprise Integration, Geographical Information System (GIS), Infrastructure Management, Internet of Things, Microsoft Dynamics, Oracle, Sales force, SAP, System Integration, Testing. Larsen \& Toubro InfoTech has 39 registered offices in 23 countries. Operational strategy of a firm includes the best practices of the firm, quality and time management, innovation in production and operation, automation, wastage policies, resource utilization etc [1]. Some of the operation strategies through smart product and services which the company has maintained to improve the productivity, profitability and reputation are as follows:

\subsection{SMART PRODUCTS AND SERVICES FOR IMPROVING THE OPERATIONS:}

a. Data Analytics: Today business has access to extraordinary volumes of data, originating from social media, connected devices, as well as transactional data and enterprise data sets. With the help of smart strategies and the right Big Data solutions, they can convert this huge data into a nucleus strategic asset.

b. Cloud solution: LTI helps their clients to digitalize the activities and performance, offer cloudbased solutions over traditional on-premises one which accelerates deployment, optimized costs and on-demand scalability associated with Cloud and Software-as-a-Service (SaaS) models.

c. Analytical and information management: This strategy access extraordinary volume of data, originating from social media, connected devices, as well as transactional data and enterprise data sets.

d. Mobile services: Enable Enterprise Resource Planning(ERP) \& reporting or exposing on Mobile devices, testing, porting and support, user experience enhancement Application development, innovative platforms like MADP and EMM Platform implementation, mobile App factory, frontend engineering are some of the operational innovative strategies used by L\&T InfoTech.

e. Enterprise Integration: Business process modeling and implementation, Architecture consulting and implementation, rollout \& support in enterprise integration process, Complex Event Processing in order to untangle the problems. This is one of the biggest step taken by L\&T to improve the quality, time management and also it an innovative idea to increase the production and operation. 


\section{MARKETING STRATEGIES :}

L\&T InfoTech has an extraordinary marketing strategy in order to attract the client all over the world. The marketing strategy enforces the marketing mix of Larsen \& Toubro which analyses the brand and company that covers 4Ps (Product, Price, Place, Promotion) of marketing mix [1], [16], [21].

(1) Product

Larsen \& Toubro or L\&T is one of the largest Indian conglomerates serving and helping across industries like heavy engineering, power, shipbuilding etc. Larsen \& Toubro also gives services like financial services, IT consulting etc under their product mix.

L\&T Realty is a real estate development corporation and undertakes various projects including the construction of residential houses and buildings, corporate office, retail, leisure and entertainment spaces for their clients. The major projects include Crescent Bay, Emerald Isle, Sea woods Grand Central, Eden Park.

L\&T Technology provides engineering services offering design, development and testing services for the industrial products, medical devices, aerospace, and telecom industries.

L\&T Solar undertakes solar energy projects. L\&T commissioned India's largest solar photovoltaic power plant (40 MWp) in 2012.

L\&T manufactures electrical and electronic products and systems. Larsen \& Toubro manufactures custom-engineered switchboards for various industrial sectors like power, petrochemicals, refineries, and cement.

Larsen \& Toubro InfoTech Limited offers information technology services with a focus on manufacturing, BFSI and communications and embedded systems. In Machinery and industrial products segment the company manufactures, and provides service support for construction and mining machinery, including surface miners, aggregate crushers, supplies rubber processing machinery hydraulic excavators and manufactures industrial valves and allied products along with application-engineered welding alloys.

(2) Price:

Larsen \& Toubro has ventured into miscellaneous product portfolio and it has estimated income of $100,000+$ crores at end of the financial year 2015-16. L\&T has used penetration-pricing strategy to come into the market and hence bids for tenders as per market situations. Larsen \& Toubro has occupied numerous government projects that include construction of bridges, dams, and canals. The pricing decisions are affected by environmental factors and the economy. The fall in commodity prices has a negative impact on the economy in terms of reduced profitability leading to financial distress in business.

(3) Place:

Larsen \& Toubro has a considerable global presence through its contributions. For real estate development, the company operates in Western and Southern India for constructing housing, retail, leisure corporate office, and entertainment properties. L\&T Technology Services functions in 30 locations in the world, which includes Germany, Italy, Netherlands, Norway, Poland, Sweden, United Kingdom, Japan, South Korea, India, USA, Canada, Belgium, Denmark, Finland, France, Singapore, and UAE. L\&T InfoTech has 39 registered offices in 23 different countries. Industrial and Machinery commodities of L\&T can be purchased from various distributors around the country or the world. in order to procure government projects, it goes all the way through the tender process and bids for tenders.

(4) Promotion:

Larsen \& Toubro has always been a company which has focused on advertising and marketing for creating brand awareness. The promotion and marketing activities in its marketing mix are done by 360 branding that is using commercials, sponsorship of events, publicity, using all media etc. L\&T has received several awards for its services, which include Rajiv Gandhi National Quality Award given to Bangalore division and Golden Peacock National Quality Award in 2012 to L\&T power. L\&T was ranked among the top companies by Newsweek in its global list of industrial sector for being a green company. Larsen \& Toubro advertise and inform its customers through its campaigns programmes through electronic and print media, social media, and billboards. It mentions that their business is motivated by a focus on sustainable practices that have a commitment to the communities. In 2017 it 
has won FICCI Quality Systems Excellence Awards for Industry - Platinum Prize in Construction Sector' in the Large Size Organisations category. L\&T has released several advertisements on TV and social media promoting its brand. Hence the marketing mix of Larsen \& Toubro (L\&T) is completed.

\section{RECRUITMENT STRATEGY \& TRAINING STRATEGY :}

L\&T identifies their candidate through a strategic approach in order to utilize the skills and knowledge in an effective and efficient manner. The recruitment and selection of L\&T is part of talent acquisition which includes the activities like screening, interviewing, sourcing, selecting, assessing and hiring. As per the information from the month of November 2017, the number of employee strength of L\&T InfoTech is more than 22,000. In order to achieve the company's goal skilled and qualified employees are required [18], [24].

\subsection{RECRUITMENT METHODS USED BY L\&T INFOTECH}

1. Promotion and transfer method: Promotion is an upward movement of employees within the organization to another job, higher in the hierarchy of the organization. In L\&T the employees will find a change in position, salary, status, responsibility, and designation.

2. Job posting and job bidding: Job posting is one way of recruiting the people to the company through posting the vacancy in various site so that the general public will come to know about the opportunities. It is an advertisement made by the human resource staff or recruiter that alerts the current employees or general public about an immediate or future job opening within the company. Job bidding is a process done by L\&T in which the applicants are required to compete with other applicants for a job position that has been posted by the employer i.e., human resource staff or organization.

3. Employee referrals: In L\&T employee referral is a common procedure of recruiting employees. It is an internal recruitment method employed by organizations to identify potential candidates from their existing employee's social network.

4. Campus recruitment: L\&T recruits candidates from top colleges in the country by undertaking an organised program of attracting and hiring students who are about to graduate from colleges and universities.

5. Advertisements in newspapers ads, television ads etc.: L\&T will give ads on various social media about the opportunity offered with proper job description to the eligible candidates who are qualified for the job.

\section{Recruitment in L\&T is done through talent acquisition by the following way (fig. 1):}

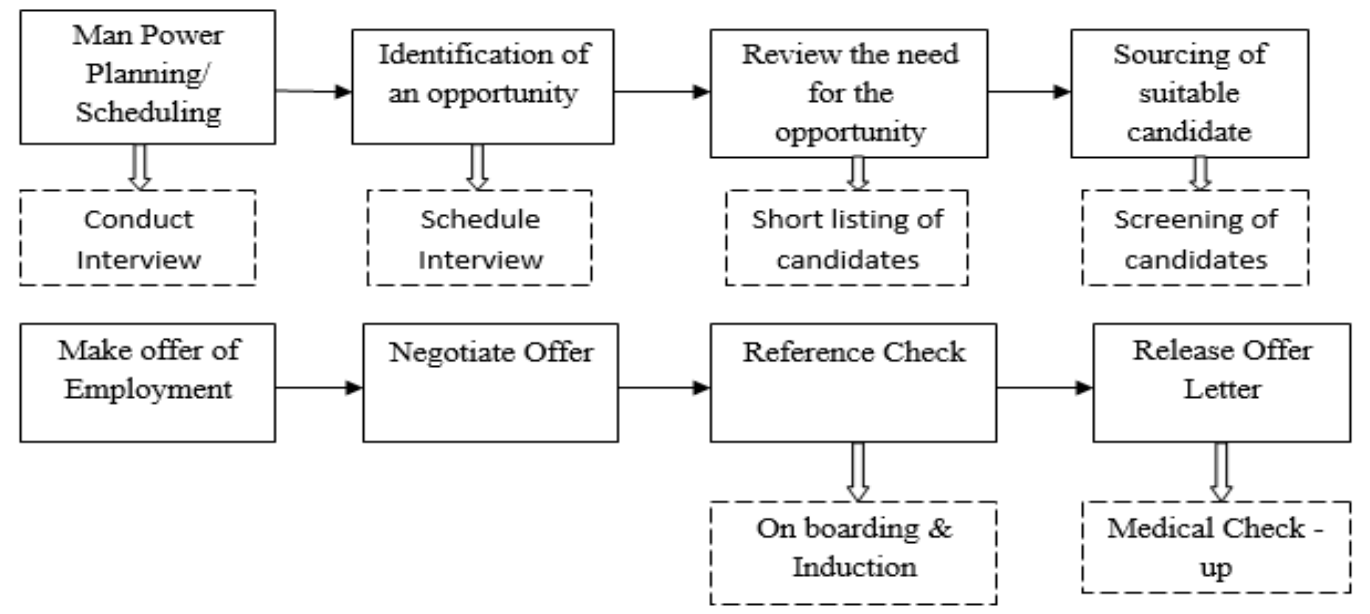

Fig. 1 : Block diagrammatic representation of Recruitment process in L\&T.

The company recruit through third-party methods which include:

1. Internet recruiting: Online or internet recruitment of L\&T is the process of matching people to appropriate jobs, using the Internet. The most frequent form of online recruitment done by L\&T through advertising of the job openings on job sites and corporate sites. This may generate a lot of responses, but simply attracting large numbers of potential candidates is only part of the online 
recruitment process. The real benefit of online recruitment is apparent when recruiters streamline the recruitment process by automation through HR software.

2. Private employment search firms: They are agencies which are linked with L\&T which specialized in recruiting executive personnel for companies.

3. Employment exchange: L\&T hires candidates through employment exchange which provide candidates to a company on the basis of their qualification and experience. The company will post their employment vacancies by means of employment exchanges and select from amongst the registered candidates as per their needs.

4. Gate hiring and contractors: L\&T do direct recruitment which is known as gate hiring. They put up a notice on the notice board regarding the job availability, such that the candidate sees it and apply for the job directly.

5. Unsolicited applications/ walk-ins: The job seeker comes to the company casually and either mail or drop in their job applicants seeking job opportunity [28].

\subsection{TRAINING STRATEGY:}

At L\&T Learning \& Development is a strategic business function contributing significantly to organisational, group and individual effectiveness \& growth by fostering a strong learning culture.

L\&T InfoTech focuses on the following thrust areas:

1. Deliver results and impact organizational performance

2. Constantly check on quickly varying environment and provide employees with the required qualities, knowledge, and skills

3. Leadership development

4. Develop corporate citizens

5. Deliver a global MNC and global leaders

6. Focus on action-oriented training

7. Synergise \& optimize efforts - avoiding overlap and duplication and build a uniform curriculum.

A culture of continuous learning and development exists all the way through structured core developmental programmes, conducted by reputed institutions for employees to develop better-quality management skills and capabilities.

A host of strategic and behavioural programs are also conducted to address specific training and developmental needs of employees [1], [2], [19].

\section{FINANCIALS MANAGEMENT :}

Larsen \& Turbo InfoTech is one of global IT service provider among top 20 which have more than 20,000 employees. They had annual revenue of \$970 million during the financial year 2017. According to the annual report of L\&T InfoTech, there is an increase of 9.3\% in revenue in 2017 as compared to 2016 when it is expressed in US dollars and there is an increase of $11.2 \%$ in revenue in 2017 as compared to 2016 when it is expressed in Indian Rupee (table 4).

Table 4: Comparison of sources of fund or the capital of the company during the past 5 years [4], [5], [24].

\begin{tabular}{|l|l|l|l|l|l|}
\hline Sources of Funds & Mar-17 & Mar-16 & Mar-15 & Mar-14 & Mar-13 \\
\hline $\begin{array}{l}\text { Total Share } \\
\text { Capital }\end{array}$ & 186.59 & 186.3 & 185.91 & 185.38 & 123.08 \\
\hline $\begin{array}{l}\text { Equity Share } \\
\text { Capital }\end{array}$ & 186.59 & 186.3 & 185.91 & 185.38 & 123.08 \\
\hline Reserves & $50,029.93$ & $43,790.25$ & $40,707.59$ & $37,506.98$ & $33,716.41$ \\
\hline Net worth & $50,216.52$ & $43,976.55$ & $40,893.50$ & $37,692.36$ & $33,839.49$ \\
\hline Secured Loans & $50,599.30$ & $50,345.11$ & $46,444.08$ & $54,229.40$ & $35,911.45$ \\
\hline & $43,376.97$ & $40,416.58$ & $35,823.14$ & $25,923.51$ & $18,776.57$ \\
\hline
\end{tabular}


International Journal of Case Studies in Business, IT and Education (IJCSBE), ISSN: 2581-6942, Vol. 2, No. 1, June 2018.

\begin{tabular}{|l|l|l|l|l|l|} 
Total Debt & $93,976.27$ & $90,761.69$ & $82,267.22$ & $80,152.91$ & $54,688.02$ \\
\hline Minority Interest & $3,563.60$ & $6,768.78$ & $4,998.62$ & $3,179.18$ & $2,652.87$ \\
\hline Total Liabilities & $\mathbf{1 , 4 7 , 7 5 6 . 3 9}$ & $\mathbf{1 , 4 1 , 5 0 7 . 0 2}$ & $\mathbf{1 , 2 8 , 1 5 9 . 3 4}$ & $\mathbf{1 , 2 1 , 0 2 4 . 4 5}$ & $\mathbf{9 1 , 1 8 0 . 3 8}$ \\
\hline
\end{tabular}

From the table 4, we understand that the fund used for financing the company has been increased in every financial year. The share capital of the company has increased to 186.59 crores on 2017 from 123.08 crores from 2013. Equity shares of the company showing an increase in the past 5 financial years. It shows an increase of $51 \%$ as compared to the year 2013. Reserves of the firm have been increased during the past 5 years. The net worth of the firm in the year 2013 was 33,839.49 and there is an increase of $11 \%$ in the year 2014 and there is an increase of $48 \%$ from 2013 to 2017 . There is comparatively a slight decrease in the secured and unsecured loans as compared from the past 5 years that means there is a decrease in the company's liability position. Total liability of the firm has increased to 62\% from 2013 to 2017. Table 4 displays the application of fund or the Assets of the company in which they run the overall working of the enterprise [4], [5].

Table 5 : The application of fund or the Assets of L\&T InfoTech [4], [5].

\begin{tabular}{|l|l|l|l|l|l|}
\hline $\begin{array}{l}\text { Application of } \\
\text { Funds }\end{array}$ & Mar-17 & Mar-16 & Mar-15 & Mar-14 & Mar-13 \\
\hline Gross Block & $16,040.33$ & $53,972.83$ & $44,049.29$ & $40,028.11$ & $36,505.42$ \\
\hline $\begin{array}{l}\text { Less: Revaluation } \\
\text { Reserves }\end{array}$ & 0 & 15.18 & 15.57 & 19.25 & 20.2 \\
\hline $\begin{array}{l}\text { Less: Accum. } \\
\text { Depreciation }\end{array}$ & $2,966.42$ & $10,716.27$ & $9,336.24$ & $7,775.86$ & $6,072.23$ \\
\hline Net Block & $13,073.91$ & $43,241.38$ & $34,697.48$ & $32,233.00$ & $30,412.99$ \\
\hline $\begin{array}{l}\text { Capital Work in } \\
\text { Progress }\end{array}$ & $16,901.14$ & $17,514.96$ & $15,548.72$ & $14,323.73$ & $11,306.81$ \\
\hline Investments & $19,753.03$ & $10,080.03$ & $9,612.12$ & $8,108.97$ & $8,767.50$ \\
\hline Inventories & $4,139.74$ & $5,361.95$ & $6,518.19$ & $5,527.46$ & $5,169.47$ \\
\hline Sundry Debtors & $27,969.60$ & $35,989.94$ & $30,089.37$ & $26,384.55$ & $23,014.91$ \\
\hline $\begin{array}{l}\text { Cash and Bank } \\
\text { Balance }\end{array}$ & $5,572.49$ & $5,901.59$ & $5,756.21$ & $4,096.57$ & $3,571.54$ \\
\hline $\begin{array}{l}\text { Total Current } \\
\text { Assets }\end{array}$ & $37,681.83$ & $47,253.48$ & $42,363.77$ & $36,008.58$ & $31,755.92$ \\
\hline $\begin{array}{l}\text { Loans } \\
\text { Advances }\end{array}$ & $1,24,649.76$ & $1,09,419.69$ & $91,946.44$ & $79,329.20$ & $60,841.63$ \\
\hline $\begin{array}{l}\text { Total CA, Loans } \\
\text { \& Advances }\end{array}$ & $1,62,331.59$ & $1,56,673.17$ & $1,34,310.21$ & $1,15,337.78$ & $92,597.55$ \\
\hline Current Liabilities & $61,118.35$ & $81,524.16$ & $61,911.03$ & $45,682.13$ & $49,021.51$ \\
\hline Provisions & $3,184.93$ & $4,478.36$ & $4,098.16$ & $3,296.90$ & $2,882.96$ \\
\hline $\begin{array}{l}\text { Total CL \& } \\
\text { Provisions }\end{array}$ & $64,303.28$ & $86,002.52$ & $66,009.19$ & $48,979.03$ & $51,904.47$ \\
\hline $\begin{array}{l}\text { Net Current } \\
\text { Assets }\end{array}$ & $\mathbf{9 8 , 0 2 8 . 3 1}$ & $\mathbf{7 0 , 6 7 0 . 6 5}$ & $\mathbf{6 8 , 3 0 1 . 0 2}$ & $\mathbf{6 6 , 3 5 8 . 7 5}$ & $\mathbf{4 0 , 6 9 3 . 0 8}$ \\
\hline Total Assets & $\mathbf{1 , 4 7 , 7 5 6 . 3 9}$ & $\mathbf{1 , 4 1 , 5 0 7 . 0 2}$ & $\mathbf{1 , 2 8 , 1 5 9 . 3 4}$ & $\mathbf{1 , 2 1 , 0 2 4 . 4 5}$ & $\mathbf{9 1 , 1 8 0 . 3 8}$ \\
\hline The anove men & & & & & \\
\hline
\end{tabular}

The above mentioned table explains the value and resources of L\&T InfoTech during the years 2013 to 2017. The investment of the firm has increased from 2013 to 2017 at the rate of $125 \%$. The cash and bank balance of the firm has increased over the past 5 years of financial data. The total current asset of the firm has increased to $18.6 \%$. The total asset of the firm has increased to $62 \%$ from 2013 
to 2017. The growth and increase of the assets will show the overall growth of the firm and it is the outcome of continuous rigid work of the firm in the field.

\subsection{LIQUIDITY OF THE FIRM}

Table 6: The table deals with the Liquidity of the firm from 2013 to 2017 [4], [5].

\begin{tabular}{|l|c|c|c|c|c|}
\hline Liquidity Ratio & $\mathbf{2 0 1 7}$ & $\mathbf{2 0 1 6}$ & $\mathbf{2 0 1 5}$ & $\mathbf{2 0 1 4}$ & $\mathbf{2 0 1 3}$ \\
\hline Current Ratio (X) & 2.55 & 1.89 & 2.13 & 1.76 & 1.6 \\
\hline Quick Ratio (X) & 2.55 & 1.89 & 2.13 & 1.76 & 1.6 \\
\hline $\begin{array}{l}\text { Dividend Payout Ratio } \\
\text { (NP) (\%) }\end{array}$ & 18.13 & 62.98 & 62.11 & 61.05 & 54.13 \\
\hline $\begin{array}{l}\text { Dividend Payout Ratio } \\
\text { (CP) (\%) }\end{array}$ & 16.24 & 56.72 & 55.59 & 56.76 & 48.71 \\
\hline $\begin{array}{l}\text { Earnings Retention Ratio } \\
(\%)\end{array}$ & 81.87 & 37.02 & 37.89 & 38.95 & 45.87 \\
\hline $\begin{array}{l}\text { Cash Earnings Retention } \\
\text { Ratio (\%) }\end{array}$ & 83.76 & 43.28 & 44.41 & 43.24 & 51.29 \\
\hline
\end{tabular}

The current ratio of the firm shows good financial position from the year 2013 to 2017 as the ratio of liquidity is $1: 2$. The quick ratio of the firm also shows an increase in its liquidity position and also there is an increase of 0.95 increases in the ratio from 2013 to 2017. Dividend Payout Ratio, Earnings Retention Ratio, Cash Earnings Retention Ratio has been increased from 2013 to 2017 (Table 6).

\section{L\&T SOLUTIONS :}

\subsection{Data and Analytical solution}

This solution provides a platform called "data engineering and analytical platform" which helped the banking and financial institutions make a quantum leap in business transformation and helped them to make more sturdy decisions. The solution helps to reduce effort in the formation of new-fangled regulatory reports, time management in the improvement of case investigation and operational stability for data acquisition.

\subsection{Automation Products \& Systems}

Due to its instinctive advantages of smart usage of resources, automation has been used and applied in almost all industries around the world. With the help of automation, they help enable to save energy and materials while improving quality, accuracy, and precision. Understanding this benefits world has moved to automation. At L\&T they provide a range of automation solutions for these newly developed needs [1], [20]. They have a wide portfolio of these automation products and solutions. They have been offering their automation solutions for :

1. Substation applications offer IPCS, EMCS, PMS, LSS

2. Building automation offer smart products like CCTV, Fire alarm systems, home automation

3. Industrial automation offerings include PLCs, HMIs, soft starters etc.

\subsubsection{Compact substation}

Electrical substation, one of the integral parts of the electrical distribution system has undergone many changes in terms of technology, components, and forms. Today they need substations which are compact as well as power efficient. To meet this need L\&T offers compact substations which are also known as Pre-fabricated substations, Package Substations (PSS) or Unitized substations (USS). A compact substation is a ready-to-install product and saves on space, time and cost of a complete project. A factory assembled product typically houses MV switchgear, transformer \& LV switch gears. This modular substation is an ideal solution for smart cities and finds its application across almost all industries due to its features:

1. Factory assembled and ready to install

2. Compact Construction

3. Ease of access to components

4. Reduction in installation space, cost \& time [1], [20].

\subsection{Control and Automation}


The Control \& Automation business of L\&T offers integrated Electrical \& Automation solutions for Oil \& Gas, Cement, Metal and other Manufacturing industries, Infrastructure as well as utilities like Power and Water. They have experience of over four decades in diverse segments and proven capabilities across the entire value chain - comprising Proposals, Design, Engineering, Project Planning, Integration, Software Development, Integrated testing / FAT, Commissioning / SAT and After-Sales Service. They assume single point responsibility to deliver complete engineered solutions based on customer needs.

10.4 Integrated solutions: Electrical, Drives, Automation, SCADA, Instrumentation, Telecommunication \& IT. C\&A delivers value through comprehensive solutions that are based on varied technology platforms and incorporate the benefits of its wide-ranging experience. Customers are served through a team of engineers who architect solutions backed by robust engineering and software development teams \& domain experts. They are the largest System Integrator in the country and 3rd in the world ranked by Control Engineering - 2014 System Integrator Giants Winners. Their biggest strength is the ability to integrate varied components from Field Devices to the Management dashboard covering Instrumentation, Electricals, Drives, Automation, SCADA, Telecom and IT providing a complete solution based on customer need [1], [20].

\subsection{Low Voltage System}

L\&T is one the world's largest manufacturers of switchgear assemblies. They associate with customers at the project conceptualization stage and their association continues even after the project is commissioned. Their range of custom-built switchboards comprises 'draw-out' Motor Control Centres and Power Control Centres, Main Distribution Boards and Control Panels. All the assemblies manufactured at L\&T are compliant with international standards \& tested at nationally \& internationally accredited laboratories. L\&T's PCC is rated up to 6300A and houses L\&T-made Air Circuit Breakers to take care of power distribution. The MCC is rated up to 5000A with continuous up gradation \& value addition. L\&T also offers assistance in product selection, application engineering, and detailed engineering, installation and commissioning, retrofitting and up-gradation of switchboards, after-sales service, and training [1], [20].

\subsection{Medium Voltage System}

L\&T completes its product basket with a range of MV switchboards. All medium voltage switchgear, ranging from $3.3 \mathrm{kV}$ to $36 \mathrm{kV}$ are manufactured, assembled \& tested at L\&T's advanced Switchgear Works - the Works are equipped with a SF6 gas handling laboratory. All the operations \& processes implemented at their works are in accordance with international norms. Their medium voltage switchgear range includes fixed or withdrawable Air Insulated Switchgear from voltage level of 3.3 $\mathrm{kV}$ to $36 \mathrm{kV}$, Gas-insulated Switchgear from $12 \mathrm{kV}$ to $36 \mathrm{kV}$ \& Ring Main Unit [1], [20], [29].

\subsection{Meters}

L\&T is a leading player in the electricity metering segment in India. Having entered the market in the early 90s on the strength of its indigenously designed single-phase and poly-phase meters, it has over a decade's experience in design, manufacturing, and supply of electronic electricity meters to Indian utilities. Since then, a strong emphasis on design and testing, coupled with the ability to meet utilities' express and implied needs has resulted in the development of meters that are accurate, easy to read and more importantly reliable on the Indian distribution network. L\&T's meters and metering solutions have found wide acceptance in India from all its major customers including industries, private utilities, electricity boards, transmission companies and generation companies and they also export meters to select countries in Africa and Asia, where the products have gained wide acceptance [1], [20], [29], [30].

\subsection{Marine Solutions}

Marine Solutions is the approved manufacturer of the switchboard and all other equipment of power distribution chain along with the control \& automation solutions for the ships of Indian Navy and Indian Coast Guard. L\&T undertake engineering and manufacturing of Custom Built Systems like switchboards, distribution boards, starters and control systems for applications onboard Naval Ships as well as Commercial Ships and they also devised automation solutions involving PLC based Control Panels etc. With a full set of in-house capabilities, L\&T offers Total Ship Electricals, Platform Management systems and, Alarm \& Monitoring solutions for marine applications. They have extensive in-house capabilities in the functions of R\&D, Design, Manufacturing, Quality 
Control, after sales etc. The marine team has 100 plus qualified and experienced engineers for various functions viz. Sales \& Marketing, Design \& Engineering, Supply Chain Management \& Outsourcing, Manufacturing \& QC and After Sales Service. L\&T's Platform Management Systems include APMS, IPMCS, IBS, Alarm \& Monitoring and Vessel Management System solutions for Naval, Coast Guard and, commercial ships. These systems typically provide propulsion control \& monitoring, CCTV systems, Fire detection systems and tank level monitoring amongst various other monitoring \& control functions. Total Ship Electricals include complete design of a ship's electrical system; engineering and supply of switchboards and all other equipment of the power distribution chain. L\&T is one of the major suppliers of electrical \& automation solutions to shipyards for the commercial vessels. The concept of reducing manpower onboard any commercial ship is widely accepted across all owners. Hence, with the advanced technology, it is pertinent to have control and monitoring of major equipment on a common platform. L\&T provides solutions for the Alarm Monitoring System / Vessel Management System for the commercial ships. Each project is given due importance and is customized as per owner's requirements. L\&T provide engineering support to the customer throughout the execution of projects which ensures smooth execution [1], [20], [29], [30].

\subsection{Modernisation Solution}

Monitoring the system and investing in the system up gradation and modernisation is absolutely essential to remain competitive in the market. L\&T's FitRight solutions can help to prepare a comprehensive modernisation programme for your electrical and automation system.

FitRight solutions help you plan and implement initiatives to improve your :

1. Process - improving productivity, quality and reducing cost

2. Safety - upgrading your installation for enhanced safety and conformance to latest standards

3. Efficiency - Reduce losses and optimize processes

4. Reliability - Improve system uptime and eliminate breakdowns

5. Power quality - Enhance power quality to support a more stable operating environment

L\&T's modernization solutions open up a new range of possibilities to extend the life of your installation, improving the utilization of assets and migration to a new environment friendly, efficient and reliable tomorrow [1], [20], [29], [30].

\subsection{Engineered Tooling Solution}

ETS is L\&T's tooling and precision machining business unit. It was established as a centre for manufacturing excellence and lives by its motto: "Where every micron matters". With 2 design \& manufacturing centres, ETS has served the industry for over 50 years as a total solution provider. They offer a range of Tooling Solutions to the electrical, automotive, medical, packaging, electronics, automation, and aviation segments, and Precision Machining Solutions to the defence, nuclear, aerospace and aviation segments [1], [20], [29], [30].

\subsection{Integrated software solutions}

L\&T's Control \& Automation business offers integrated electrical and automation solutions to diverse industry segments, such as oil \& gas, water, utility, minerals \& metals, power, solar energy, manufacturing, food and beverage, automobiles, chemicals, pharmaceuticals and, infrastructure. The business has enhanced the effectiveness of a wide and varied client base with a complete range of customized electrical and automation solutions - encompassing instrumentation, electrical, drives, inverters, automation, SCADA, telecom and engineered IT solutions. The business has a vast installed base in India. Its distinctly superior and proven solutions stem from its expertise in automation, electrical and instrumentation acquired over the years, as well as its domain knowledge [1], [20], [30].

\subsection{Self Service solutions}

L\&T InfoTech introduced a self-service solution for companies wanting to improve efficiency, reduce reliance on IT resources, and provide internet-based access to information for both internal staffs as well as the customers. L\&T offer this solution in LTI Canada. The information is carried through different portals called WealthLink ${ }^{\mathrm{TM}}$ Investors and Advisory portals, Reporting and Analytical solution (RAS), Unitrax Output distribution service[1], [20], [30].

\subsection{Digital Video solution}

LTI's media and entertainment IT solutions and consulting services help media companies to deliver superior customer satisfaction and improve operational efficiency by enabling the media entities to create better content and also in managing distribution and rights management [1], [20], [29]. 


\subsection{Regulatory and Compliance Solution}

This solution is provided in LTI Canada which helps the company to constantly track legislative and regulatory compliances solutions to change the business needs according to the latest industry standards.

\subsection{AML Add-on solutions}

Anti-Money Laundering suite is a set of add-on solutions and tools built on the proprietary Mosaic framework. This AML Add-on solution is scalable and flexible and can be implemented to augment the capability of client's existing AML solution [29], [30].

\subsection{Insurance Solution}

Leveraging a combination of rich insurance domain experience, strong partner ecosystem, and deep expertise of its parent L\&T group in Smart Cities and Smart factories [29], [30].

\section{BUSINESS STRATEGY :}

A business strategy includes major resource issues like raising the finance to build a new factory. Business strategies are also including deciding on what products or services to allocate major resources of the company. Taken together, these processes highlight strategic insight and execution as well as general management leadership responsibility. While many organizations have several of these elements as a part of their strategy process, what is different about the L\&T approach is that they have an integrated set of mechanisms to both sense and seize opportunities. This allows the firm to consider trends in markets and technology, to identify issues that are relevant to customers, to examine them in detail, and to reconfigure assets to address them [2], [21], [22], [24]. The process begins with the recognition that matures, well-established businesses need to operate differently from new, exploratory ones. To succeed, emerging businesses have different key success factors and different styles of leadership and different alignments of people, formal organizations, and culture. L\&T recognized that the current management system rewarded short-term execution aimed at current markets. Trying to operate a new business within a mature one can be exceedingly difficult, with the result that the new business is often killed. Further, the company lacked the discipline for selecting, experimenting, funding and terminating new businesses. This led to the development of a process to identify new growth opportunities - all with senior management oversight to ensure that the new businesses get the resources needs to explore the opportunity. According to NASSCOM, the Indian IT-BPM industry size is expected to reach $\$ 225$ billion by 2020. The export business contributed $81 \%$ of total revenue of the Indian IT services market. The domestic business contributed $19 \%$ of the total revenue of the Indian IT services market. Indian IT services, from providing cost arbitrage to managing IT from a business perspective and providing enterprise digital transformation, led to improved business services, aligning and customizing according to needs of individual customers in every industry [25], [27], [29], [30].

(1) Well-built pedigree - Business-to-IT and Brand Equity of L\&T:

L\&T InfoTech is amongst the few IT service providers in the world, which is part of a diversified conglomerate, the Larsen \& Toubro group, thereby benefiting from the expertise and experience of the group in verticals like oil \& gas, hydrocarbons, heavy engineering, and automotive \& aerospace, which assist L\&T InfoTech in effectively delivering IT services and solutions to its clients among various verticals, a key differentiator among competitors [15]. NASSCOM ranked L\&T InfoTech the sixth largest Indian IT services company in 2015 in terms of export revenues. The company services span across diverse industries like banking and financial services, insurance, energy and process, consumer packaged goods, retail and pharmaceuticals, media and entertainment, hi-tech and consumer electronics and automotive \& aerospace. L\&T InfoTech offers services such as application development, maintenance and outsourcing, enterprise solutions, infrastructure management services, testing, digital solutions and platform-based solutions [25], [27], [29], [30].

\section{(2) Established long-term relationship with clients:}

L\&T InfoTech has a track record of delivering an extensive range of solutions through an integrated global delivery model, domain-specific expertise, has forged strong client relationship over the years. Out of 258 active clients, the company caters to 49 of the Fortune global 500 companies. L\&T InfoTech has been engaged with over 100 clients for more than three years. Citibank and Chevron are two of the largest clients for over 10 years with L\&T InfoTech. Citibank and Chevron contributed 
$14.9 \%$ and $5.9 \%$ in the financial year 2016. Barclays is also one of the largest clients since 2007 with $3.1 \%$ contribution to revenue in the financial year 2016. Total 17 clients generated over $\$ 10$ million in revenue, 10 clients generated above \$20 million in revenue and three clients generated over $\$ 100$ million revenue in FY16. L\&T InfoTech has a history of high client retention with 96.9\%, 98.1\%, 96.9\% from existing clients in financial years 2016, 2015, 2014 respectively.

(3) Sharpening focus on emerging technologies:

Digitisation would increasingly become systematically critical in the near future, for which the company plans to enhance digital platforms, build industry and technology frameworks, internet-ofthings (IoT), business process digitalization and end-to-end digital transformational delivery capabilities. To bring business process efficiency to clients, the company is developing automation tools to provide greater value addition propositions. L\&T InfoTech plans to invest in start-ups through seed capital thereby to benefit from innovation capabilities and digital offerings. As part of its strategic focus in India, the company is positioning itself to embark on smart cities opportunities [25], [27], [29], [30].

(4) Strong Management Culture and customer service:

L\&T InfoTech is amongst the few IT service providers in the world, which is composed of a diversified corporation. L\&T InfoTech is effectively delivering IT solutions and services to its customers along with a range of verticals, an input differentiator amongst competitors. The success of L\&T is based on customer-centric management which is composed of Leading the convergence of digital \& physical: Brand building, Experience transformation, and Portfolio mix, Learning and Growing: Talent management, and Operational excellence, Service Leadership: Acquire and grow, Key Account focus, and Delivery excellence.

(5) Global Presence \& digital deals :

L\&T InfoTech have a very extensive global presence in many countries such as North America which has 13 sales offices and 8 delivery centers, Europe which has 9 sales offices and 2 delivery centers, Middle East and South Africa has 4 sales offices and 1 delivery center, India has 9 sales offices and delivery centers, Australia has 3 sales offices, and APAC has 4 sales offices and 2 delivery centers. North America and Europe have the largest sales offices and delivery centers followed by India. L\&T InfoTech's IT services deal with Business models, Digital experience, and Processes \& Operations [25], [27], [28].

(6) New Alliances and Partnership :

In order to achieve the goals, creating new alliances are one of the business strategies which is followed by L\&T InfoTech.

Coupa: Cloud-based spend management solutions

Pega: Business Process management solutions to accelerate digital transformations.

Predix: A Cloud-based operating system for the engineering and industrial internet.

Work fusion: Helping enterprise digitalize their operation and improve productivity using operation. Workplace: Enterprise collaboration platform [27].

\section{CORPORATE SOCIAL RESPONSIBILITY :}

L\&T follows an exclusive approach to Corporate Social Responsibility. They attempt to make a positive impact on the environment at the organizational level, as well as on improving their organization's sustainability. At an individual level also they try to make a difference. All employees are making meaningful contributions to the community through its CSR initiative. Their social initiatives help give power to communities through programs focused on bringing about a positive change. With a dedicated team of volunteers, the company help to enhance the skills of marginalized youth and women, improve the quality of education for children of marginalized communities, provide special education and skills for the physically and intellectually challenged people, and address the crucial issue of environment conservation and their projects help promote sustainable community development, with an obligation to promote the cause of creating a more inclusive society [23], [24].

Through their initiatives, they ensure that their employees, who are an integral part of the 1Step initiative, grow as complete individuals and they make an effort which is focused on shaping them 
into true leaders, capable of dynamic change, rising above the situation, and most importantly, developing a holistic perspective and approach toward life [1], [23], [25], [26].

Larsen \& Toubro Limited fosters a culture of caring, trust, and continuous learning while meeting the expectations of all stakeholders and society at large. As a responsible Corporate Citizen, the Company contributes towards inclusive growth by empowering communities and accelerating development. The Company's CSR Policy framework details the mechanisms for undertaking various programmes in accordance with section 135 of the Companies Act 2013 for the benefit of the community [23], [24], [25].

\subsection{THEME OF CORPORATE SOCIAL RESPONSIBILITY OF L\&T INFOTECH ARE:}

- Water: It is included in limited programmes which are making clean drinking water available, preservation and refining of water.

- Education: Education infrastructure confined to educational Institutions, nurturing talent at different levels, and educational programmes.

- Health: It includes community health centers, centers for elderly/disabled, general and specialized health camps and outreach programmes, mobile medical vans, dialysis centers, support to HIV / AIDS programme.

- Skill Development: It is limited to vocational training such as support to ITI's, women empowerment, skill building, support to specially abled (infrastructure support \& vocational training), computer training, CSTI's, provides employability skills at project sites, creating training centers.

\subsection{BUDGET OF CORPORATE SOCIAL RESPONSIBILITY:}

- The Company's Board shall allot as a minimum 2\% of the average profit during the three preceding financial years.

- The Company could pool resources and funds through other entities to undertake CSR activities.

- In case of some excess surplus arising out of CSR programmes, the surplus amount will not become a part of business profits of the Company.

12.3 ROLES AND RESPONSIBILITIES OF CSR:

The CSR Governance structure comprises of the Board, CSR Committee, Apex Sustainability \& CSR (SCSR) team, IC SCSR Teams, and Unit SCSR Teams [23, 24].

\subsubsection{The Board of Directors of the Company will :}

- Grant the CSR Policy of the Company

- Ensure use up of $2 \%$ of profits

- Disclose the CSR policy content in the CSR report and set the policy on the Company's website as programmed under Section 135 of the Companies Act 2013.

- Make sure that the social programmes undertaken are associated with the CSR policy of the Company.

- State the reasons in the report for not spending the earmarked sum of money in case the Company fails to spend the money [23, 24].

\subsubsection{CSR Committee :}

The Board has shaped the CSR Committee according to the requirements of the Act.

- Prepare and propose the CSR policy to the Board for consent

- Supervise the policy from time to time

- Advise the amount of spending to be incurred on CSR programmes

- Compose translucent monitoring system for ensuring execution of the CSR programme

- Assign the programmes to the Independent Companies ('IC's) / Corporate to implement the same [23, 24].

12.3.3 Apex SCSR Team :

- Spread knowledge concerning the accepted CSR policy

- Grant direction to IC SCSR teams and Unit SCSR teams and the IC management to guarantee that all CSR programmes are aligned with L\&T's CSR policy

- Advise programmes to be undertaken for the duration of the financial year to the CSR Committee of the Board. 
- Facilitate valuable execution of L\&T 's CSR policy across ICs and locations

- Encourage synergy amongst ICs / locations and distribute superlative practices to attain required outcome for community progress

- Develop assessable benchmarks and get the same agreed by the CSR Committee [23, 24].

\subsection{IMPLEMENTATION OF CSR :}

- CSR programme will be undertaken by the Company in recognized areas. The Company will undertake need assessments as and when necessary.

- The duration over which a particular agenda will be spread will depend on its character, amount of exposure and the intended impact of the programme.

- The Company may get into partnerships with the government, business partners and communities to generate multiplier result of its social programmes.

- The means of implementation of CSR programmes will include a mixture of straight implementation and/or through partners such as NGOs, Trusts, academic institutions, business associates, registered societies etc. The Company will select its partners after appropriate due diligence.

- The Company may utilize the services of internal teams, employee volunteers, consultancy firms, expert agencies etc [23, 24].

\subsection{MONITORING AND REPORTING}

- At the Unit and IC level:- The Company has constituted a method to supervise and report the improvement of its CSR programmes. An accounting system has been established by the Company to ensure programme wise accounting of CSR spends. The ICs/Corporate will be accountable for monitoring and implementing the CSR programmes. The Apex SCSR, IC SCSR and Unit SCSR teams and the ICs will ensure the effectiveness of its CSR programmes through third-party audits and report the CSR performance to the CSR Committee.

- At CSR Committee level: The CSR Committee will review the implementation of the CSR programmes and the CSR audit reports periodically, preferably on a quarterly basis and arrange to share in the Company the best practices.

- Re-evaluate the execution and monitoring mechanism properly.

- Report to the Board appropriately.

\subsection{ACHIVEMENTS FROM CSR}

- In 2018, L\&T achieved ISC-FICCI Award for "Best Corporate Initiative in Sanitation". L\&T received the award for its Corporate Social Responsibility sanitation programme in 16 waterstressed villages in the Bhim and Kumbhalgarh blocks of Rajsamand district in Rajasthan.This award reinforces L\&T's commitment to 'Building India's Social Infrastructure' - ensuring a better quality of life for communities to achieve inclusive growth through empowerment.

- In 2017, L\&T achieved FICCI CSR Award for innovative work in integrated community development for rural communities, as part of its CSR initiatives. The award was conferred in the category of Health, Water, and Sanitation for Private Sector Companies. Watershed initiatives undertaken through L\&T's flagship Integrated Community Development Programme are implemented across five locations in three states. Communities in these locations have seen a significant increase in their water availability, crop productivity and community participation in decision-making over the project period.

- In 2017, L\&T achieved "ASSOCHAM's 'Responsible Organizational Excellence Award' for CSR. L\&T's CSR is aimed at the theme of 'Building India's Social Infrastructure'. The initiatives undertaken through L\&T’s flagship Construction Skills Training Institutes (CSTIs), which provide residential training to school dropouts and migrant labour, were lauded by the jury headed by Justice Mr. V.N. Khare, Former Chief Justice of India. This award once again provides recognition and reinforcement to L\&T's commitment towards 'Building India's Social Infrastructure' and reaching out to the most underserved segments through its innovative community development initiatives.

- In 2017, L\&T achieved Best Practices Award for sustainable development goal. The award was based on a case study on the skilling initiative undertaken through L\&T's flagship 
Construction Skills Training Institutes (CSTIs), which provide residential training to school dropouts and migrant labor. The case study presented a link between the efforts of L\&T at the community level with its commitment towards the UN's SDGs which contain 17 developmental goals with 169 targets, ratified by 193 member countries of the UN.

\section{SWOT ANALYSIS :}

SWOT analysis is a business study technique that every organization can perform for each of their products, services, and markets while deciding on the most excellent method to accomplish future growth. This analysis process involves identifying the strength and weakness of the organization, and threats and opportunities present in the market that they operate in.

\section{Strength:}

- Enlarged business: L\&T is a large business which operates in 27 countries and provides IT products and services according to the need of the client which they serve. They have more than 20,000 employees all around the world who works to achieve the common goal of gaining maximum profitability in the concern sector. Extensive global presence in many countries such as North America which has 13 sales offices and 8 delivery centers, Europe which has 9 sales offices and 2 delivery centers, Middle East and South Africa has 4 sales offices and 1 delivery center, India has 9 sales offices and delivery centers, Australia has 3 sales offices, and APAC has 4 sales offices and 2 delivery centers.

- Large number of products: L\&T is a multinational company which involved in Banking, Insurance, Energy and Utilities, CPG \& Retail, Hi-tech, Life Science and Healthcare, Media and Entertainment, and Manufacturing. They offer a large number of products to the customers in different sector they work in such as Services like Cloud, Consulting, Cloud Infrastructure and Security, Assurance service, Cybersecurity, Applications Management, Enterprise Solutions: Oracle, SAP, Microsoft Dynamics, Cloud apps, Maximo, Salesforce, Digital Transformation: Data \& Analytics, Internet of things, Mobility, Digital Integration, Artificial Intelligence and cognitive, Platforms: Mosaic, Industry Platform (Unirax, redaxis, iceon), Technology Platform.

- Strong management: L\&T is an Indian based multinational company which have a strong management which controls the entire business in 27 different countries and provides services. The company is success because of the employees who are satisfied in the job and outstanding human resource management of the firm.

- Stable financial position: L\&T is one of the leading company which have a stable profit throughout there working. It is one among the top 10 companies in the world who have a large market capital and sales in the market. The company have a stable liquidity from past five years.

- Strong Customer Base: Since the company have long run experience in the market, they have a lot of loyal customers who opt only L\&T. Other than experience they provide, the service to their customer and brand image of the company attracts the customer to stay with the company. And also provide a large number of services which other companies that doesn't provide.

- Present in global market: L\&T has a global presence in 27 countries which have9 sales offices and 2 delivery centers, Middle East and South Africa has 4 sales offices and 1 delivery center, India has 9 sales offices and delivery centers, Australia has 3 sales offices, and APAC has 4 sales offices and 2 delivery centers.

\section{Weakness:}

- Depend on global market: Even though L\&T is an Indian Company, they depend too much on the international market. In one scenario it is true that they earn maximum profit from the global or international clients but in the international market, the risk of losing the market has a high chance. So investing and concentrating too much on the global market by ignoring the home market is a weakness for the country.

- High customer concentration: When there is high customer concentration the company may gradually have tension. They may have the fear that the bank will limit the amount they will advance from any customer accounts receivables that exceed a certain dollar amount or a predetermined percentage of sales or they may have the fear of if large number of customers switch to another company which is their competitors. 
- Exchange rate problem: L\&T carry out its business activities in 27 countries and it has a global presence in the market. It is the company which is ranked in the top 10 IT companies all over the world. Fluctuation is the exchange is one of the major issue faced by many multinational companies. A multinational company like L\&T's value is affected more than national companies by any movement in currency exchange rate. The change may affect the company's asset price, financial structure, profit margin, and cash flow through the transaction, translation risk, and economic exposure risk.

- Cash conversion: Cash conversion risk is a part of exchange rate risk because this risk is involved in the process of converting one currency into another currency. It purely depends on the foreign exchange rate of the currency concern. For the risk involved in currency conversion are the transaction, translation risk, and economic exposure risk.

\section{Opportunities:}

- Linked and associated with power sectors: L\&T deals with the power sector business and is one of the unique features of the company. L\&T Power provides the thermal power plant with concept-to-commissioning solutions and for Gas-based power plants, it also offers turnkey solutions. The Nabha Power plant in Punjab is built by L\&T which is India's first indigenously built supercritical plant. In Gujarat the Dhuvaran Plant which is built by L\&T on EPC basis.

- Provide the solution to the large sector: L\&T is the only company which provides a large number of solutions to the different sector. They provide a high-quality solution to Banking, Insurance, Energy and Utilities, CPG \& Retail, Hi-tech, Life Science and Healthcare, Media and Entertainment, and Manufacturing sectors.

- Emerging and flourishing market: L\&T has a large and flourished market all over the world. The company is extending their IT services to many other different fields and sectors. they are very keen towards their research and development in different areas and L\&T InfoTech claims to double its size in three years through organic growth and acquisition.

- Innovation in Cloud computing: LTI helps their clients to digitalize the activities and performance, offer cloud-based solutions over traditional on-premises one which accelerates deployment, optimized costs and on-demand scalability associated with Cloud and Software-as-aService (SaaS) models.

\section{Threats}

- High exposure to the foreign market: L\&T is a company which has a global exposure and have a large of clients all over the world to seek product and services from them. they have a large experience in the global market and also well aware of the market condition through different solutions created by them.

- High competition in the international market: There is a number of entities which are working in the same sector and, they compete with each other to achieve the market by earning a maximum customer and maximum profit. There are 46 competitors for L\&T in the international market with the same product and services.

- Powerful competitors: High competition in the international market will take place only when there are powerful competitors. L\&T is one of the top 10 companies in the world to provide innovative and creative products and services digitally. Even though they are the best among the ten, there is always a chance of losing the market because of the highly aggressive competitors.

- The Economic slowdown may cause a problem in the economy: Since L\&T is a global company and work in the international market, any economic slowdown may affect very badly to the company. The economic crisis will affect the currency value and the exchange rate which will adversely affect the customer concentration as well as the profit. The cash conversion rate, translation and transaction risk and economic risk will be generated as an after-effect of the economic slowdown for the company.

\section{FINDINGS \& SUGGESTIONS :}

As per our study, the organizational strategy of L\&T InfoTech is as per the suggestions of Theory of Accountability (Theory A) [31-37]. According to Theory A, the performance of an organization of $21^{\text {st }}$ century can be improved by adopting eight functional elements. The whole organization L\&T 
InfoTech has prepared itself for a collective endeavour, joint identification of need, joint policy formulation, ensuring responsibility, developing strategy and displaying creativity in achieving it so that it could prosper. The company ensured that Accountability is fixed to both individuals and teams in order to ensure success in given task through its slogan "Welcome to possible". The basic functional elements of Theory A including (1) Planning (2) Target setting (3) Motivation (4) Work Strategies (5) Responsibility (6) Role model (7) Monitoring \& Guiding and (8) Accountability which are well implemented in L\&T InfoTech. By setting the target for every internal stakeholder as per its business objective, L\&T InfoTech developed its working strategy and motivated its employees through the slogan "Welcome to Possible". The company considered its Founder Company L \& T itself as its role model. The sub-functions under these are a series of processes starting from (1) Organisation assessment to problem identification and joint policy formulation, (2) Shared understanding through communication and action planning at different organizational level, (3) Adoption of the idea and increased performance by showing and monitoring individual responsibilities, (4) Empowerment, support and teamwork using organizational strategy and technification of business processes, (5) Commitment, consistency, and target fulfilment, (6) Acknowledging example and willingness to improve, (7) Joint review, self-appraisal, and confirmation of accomplishment, and (8) Contribution through commitment and creativity, under each of the steps mentioned above, L\&T InfoTech could implement its business strategy successfully to achieve its objectives.

Based on the observations on study and analysis of L\&T InfoTech, the following suggestions are proposed:

(1) Even though L\&T has a market in the parent country, they focus mostly on the global market. They have more sales offices and delivery centers outside India. The company should have a balance on their working both in parent country as well as in global market so that if any changes happen in the global market due to inflation, tax, GDP or cost the company can survive in the parent country.

(2) When a company customer base is too concentrated on a handful of large clients, it can make the owner and management team nervous. They may fear that the bank may limit the amount of advance from any customer account receivables that exceed a certain dollar amount or predetermined percentage of sales. So that the company will be in tension and concentrate much on customer retention. There is also a significant business impact if a large number of customers switch to another company.

(3) Companies like L\&T often face exchange rate problem due to fluctuation in their rates. The risk of changing the exchange rates of the currency may affect the company's assets price, financial structure, profit margin, and cash flow. In order to save from these kinds of fluctuations, the company should concentrate more on their home country process, sales, financials, and profit.

(4) L\&T is a company which has large number of competitors like TCS, Infosys, MindTree etc. which provides same product and services to the local and international customer. L\&T has to introduce new solutions and services so that the company can perform outstanding in the engineering field.

(5) Any economic slowdown in the economy will affect the GDP, recession is highly characterized by falling of investment spending, business decline and less employment. L\&T should be prepared and has to take precautions to overcome if any economic slowdown happens. if any slowdown happens in the economy it will affect L\&T 's profitability. Economic recession also affect the stock market, the share value of the company will come down. Since L\&T is a global company any economic recession happens in one country have multiplier effect in other countries due to that many FDI of the company will be affected adversely.

(6) L\&T organizes an excellent CSR activity over many region, the mandatory $2 \%$ CSR fund is providing a lot of contribution to the society. Still the company should focus on area like education of women, employment opportunities for handicapped and waste disposal of the society in order to make some changes in the society and environment. 
(7) One of the unique features of L\&T is that they have a large number of solutions to their clients as well as for the employees to make their work more easy and reliable. The competitors who are involved in the same business do not offer the same services to their clients and customers.

\section{CONCLUSION :}

L\&T InfoTech being an Information Technology service provider could able to provide latest innovative ideas and solutions to the customers around the world. L\&T is listed as one of the top 10 listed companies in the world through its quality and quantity of service through an innovative business strategy of seeking challenges through its slogan "Welcome to possible" to various industries and industry sectors. The different strategies to improve the quality, number of solutions, and new technology adoption made L\&T InfoTech a unique company. The effort of the company to provide services for different sectors like Banking, Insurance, Energy and Utilities, CPG \& Retail, Hi-tech, Life Science and Healthcare, Media and Entertainment, and Manufacturing so as to improve the performance of such industry. In this case study, we have analysed the operational strategy, business strategy, financial stability, marketing mix, competitors, training, and recruitment strategy of L\&T InfoTech to know its overall performance as a prominent winner in the competitive environment. The case-study also presents the CSR procedure of the company and analyzed its business strategies using SWOT framework.

\section{REFERENCES :}

[1] https://www.Intinfotech.com Retrieved- on 28/02/2018.

[2] Aithal, P. S. (2017). An Effective Method of Developing Business Case Studies Based on Company Analysis. International Journal of Engineering Research and Modern Education (IJERME), 2(1), 16-27. DOI: http://dx.doi.org/10.5281/zenodo.400579.

[3] Aithal, P. S., (2016). Study on ABCD Analysis Technique for Business Models, Business Strategies, Operating Concepts \& Business Systems. International Journal in Management and Social Science, 4(1), 98-115. DOI : http://doi.org/10.5281/zenodo.161137.

[4] http://www.business-standard.com/company/l-t-infotech-18105/information/company-history Retrieved-on 09/05/2018.

[5] http://www.moneycontrol.com/competition/ltinfotech/comparison/LI12 Retrieved-on 15/05/2018.

[6] https://www.tcs.com/ Retrieved-on 28/02/2018.

[7] https://www.infosys.com/ Retrieved-on 28/02/2018.

[8] https://www.wipro.com/en-IN/ Retrieved-on 28/02/2018.

[9] https://www.hcltech.com/ Retrieved-on 28/02/2018.

[10] https://www.techmahindra.com/DAVID.html Retrieved-on 28/02/2018.

[11] https://www.oracle.com/in/industries/financial-services/index.html Retrieved-on 28/02/2018.

[12] https://www.mphasis.com/ Retrieved-on 28/02/2018.

[13] https://www.mindtree.com/ Retrieved-on 28/02/2018.

[14] https://hexaware.com/ Retrieved-on 28/02/2018.

[15] Ted, James.,(2011). Operations Strategy, Ted James \& Ventus Publishing ApS, 8-11.

[16] Nazim U. Ahmed, Ray V. Montagno, Robert J. Firenze, (1996). Operational strategy and organizational performance: an empirical study, International Journal of Operations \& Production Management, 16(5), 41-55, DOI : https://doi.org/10.1108/01443579610113933.

[17] Borden, Neil. S H. (1984), The concept of marketing mix. Journal of Advertising Research, 1(9), 2-7.

[18] Nandini, Sudheer, (2013). Effectiveness of Recruitment and Selection at L\&T InfoTech, 65-67. 
[19] http://www.larsentoubro.com/corporate/careers/learning-development/

Retrieved-on 02/03/2018.

[20]http://www.Inttechservices.com/- Retrieved on -28/02/2018.

[21] Aithal, P. S., (2017). Company Analysis - The Beginning Step for Scholarly Research. International Journal of Case Studies in Business, IT and Education (IJCSBE), 1(1), 1-18. DOI: http://dx.doi.org/10.5281/zenodo.573769.

[22] Aithal, P. S. (2017). Industry Analysis - The First Step in Business Management Scholarly Research. International Journal of Case Studies in Business, IT and Education (IJCSBE), 2(1), 1-13. DOI: http://dx.doi.org/10.5281/zenodo.810347.

[23] Larsen and Toubro Limited, "Corporate social responsibility (CSR) Policy Framework, 1-5.

[24] Kuruvilla, S., \& Ranganathan, A. (2008). Economic development strategies and macro-and micro-level human resource policies: The case of India's "outsourcing” industry. ILR Review, 62(1), 39-72.

[25] Ahmad, N. (2012). Adoption, implementation and usage of enterprise systems: an empirical study.

[26] Madhushree L.M., Revathi, R., Kumar, A., \& Aithal, P. S. (2018). Business Strategy of Top Indian IT Company: Mindtree.

[27] Kulkarni, P. (2017). Knowledge innovation strategy. Bloomsbury Publishing.

[28] Gopal, A., \& Gao, G. (2009). Certification in the Indian offshore IT services industry. Manufacturing \& Service Operations Management, 11(3), 471-492.

[29] Jaiswal, M. P., \& Sharma, A. (2001). Case study ERP systems extended to B2B ebusiness. Vision, 5(1_suppl), 46-54.

[30] Chapke, S. G. (2011). HR Practices in IT companies. Indian Streams Research Journal, 1(10), $1-4$.

[31] Aithal, P. S., \& Suresh Kumar, P. M. (2016). Organizational Behaviour in $21^{\text {st }}$ Century - Theory A for Managing People for Performance. IOSR Journal of Business and Management (IOSRJBM), 18(7), 126-134. DOI: http://doi.org/10.9790/487X-180704126134.

[32] Aithal, P. S. (2016). How to Increase Research Productivity in Higher Educational Institutions SIMS Model. International Journal of Scientific Research and Modern Education (IJSRME), 1(1), 447-458. DOI : http://doi.org/10.5281/zenodo.161037.

[33] Aithal, P. S., \& Suresh Kumar, P. M. (2016). Comparative Analysis of Theory X, Theory Y, Theory Z, and Theory A for Managing People and Performance. International Journal of Scientific Research and Modern Education (IJSRME), 1(1), 803-812. DOI: http://doi.org/10.5281/zenodo.154600.

[34] Aithal, P. S. \& Suresh Kumar, P. M. (2016). Theory A for Optimizing Human Productivity, IRAInternational Journal of Management \& Social Sciences, 4(3), 526-535. DOI : http://dx.doi.org/10.21013/jmss.v4.n3.p2.

[35] Aithal, P. S. \& Suresh Kumar, P. M. (2016). CCE Approach through ABCD Analysis of 'Theory A' on Organizational Performance. International Journal of Current Research and Modern Education (IJCRME), 1(2), 169-185. DOI: http://dx.doi.org/10.5281/zenodo.164704.

[36] Aithal, P. S. \& Suresh Kumar P. M. (2017). Interconnecting Theory A and ABC Model of Organizational Performance. International Journal of Management, Technology and Social Sciences (IJMTS), 1(1), 1-13. DOI: http://dx.doi.org/10.5281/zenodo.268598. 
International Journal of Case Studies in Business, IT and Education (IJCSBE), ISSN: 2581-6942, Vol. 2, No. 1, June 2018.

[37] Aithal, P. S. (2018). Strategic Management Research in India : Contribution of Top Business Schools during last 5 Years - A Critical Study. International Journal of Advanced Trends in Engineering and Technology, 3(1), 133-145. DOI : http://doi.org/10.5281/zenodo.1237897. 